10 Debora Retief records her father's birthday (12 November 1837) 

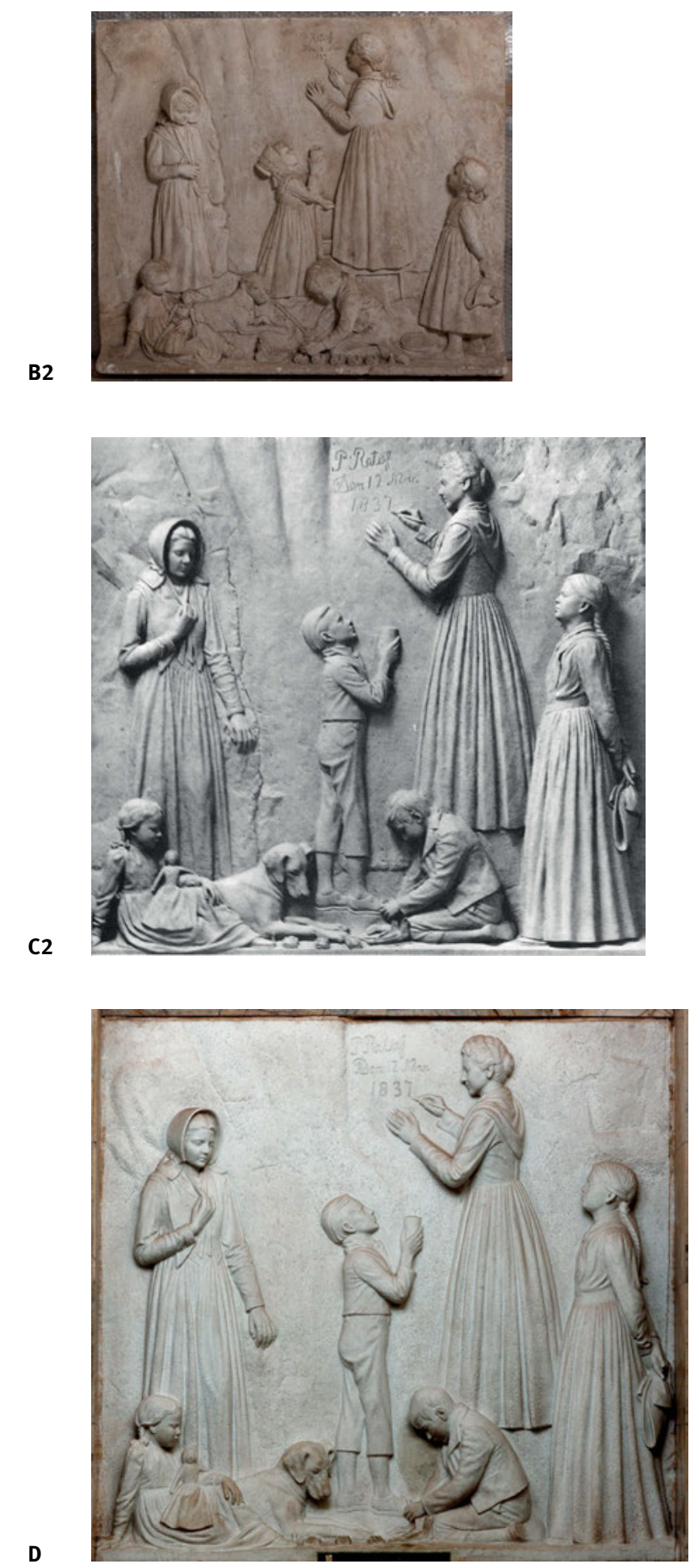


\section{Debora Retief}

South wall, south-east projection (panel 12/31)

h $2.3 \times$ w. $2.4 \mathrm{~m}$

Parts of left and top edge chipped off; vertical fractures near left edge

Sculptor of the clay panel: Laurika Postma

\section{STAGES OF PRODUCTION}

B1 One-third-scale clay maquette, not extant but replicated in B2 (1942-43)

B2 One-third-scale plaster maquette, h. $77 \times$ w. $89 \times$ d. $8 \mathrm{~cm}(1942-43)$

C1 Full-scale wooden armature, not extant (1943-46)

C2 Full-scale clay relief, not extant but photographed; replicated in C3 (1943-46)

C3 Full-scale plaster relief (1943-46), not extant but copied in D (late 1947-49)

D Marble as installed in the Monument (1949)

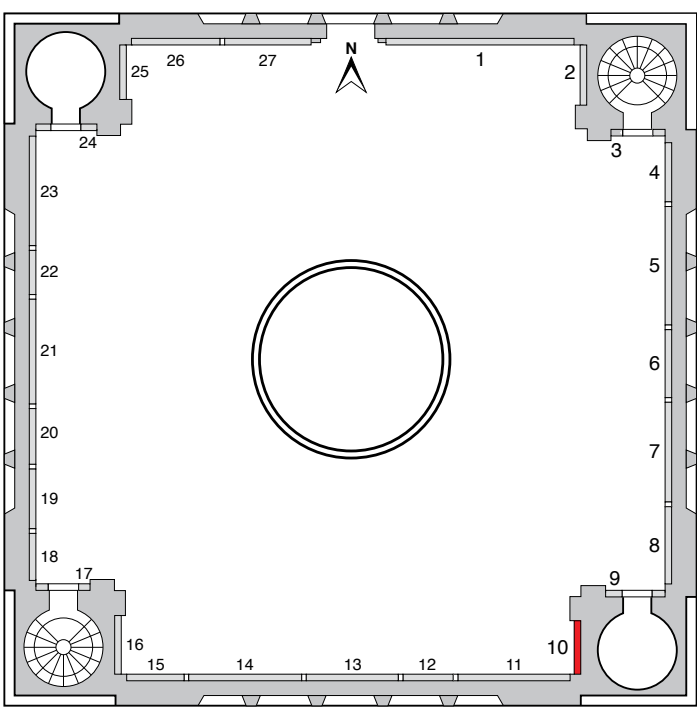

\section{EARLY RECORDS}

Jansen Memorandum (19.1.1937) - item 8 'The Voortrekkers on the Drakensberg (Blydevooruitsig) near Retiefklip' [Retief stone]. Here the camp life will be portrayed as also receipt of the news of land being obtained from Dingaan.'

Voortrekker Monument (early 1937?) - p.5 'Here will be represented the exodus from the Cape, Thaba N'Chu, Vechtkop, Kerkeberg [sic; the locale of Blydevooruitsig], the descent from the Drakensberg, the massacre, the vow, retribution, the founding of the republics' (bilingual SVK attachment, 'The Voortrekker Monument / Die Voortrekkermonument', possibly written by Moerdyk, offers a rare inclusion of Kerkenberg; NARSSA, BNS 146/73/2) 


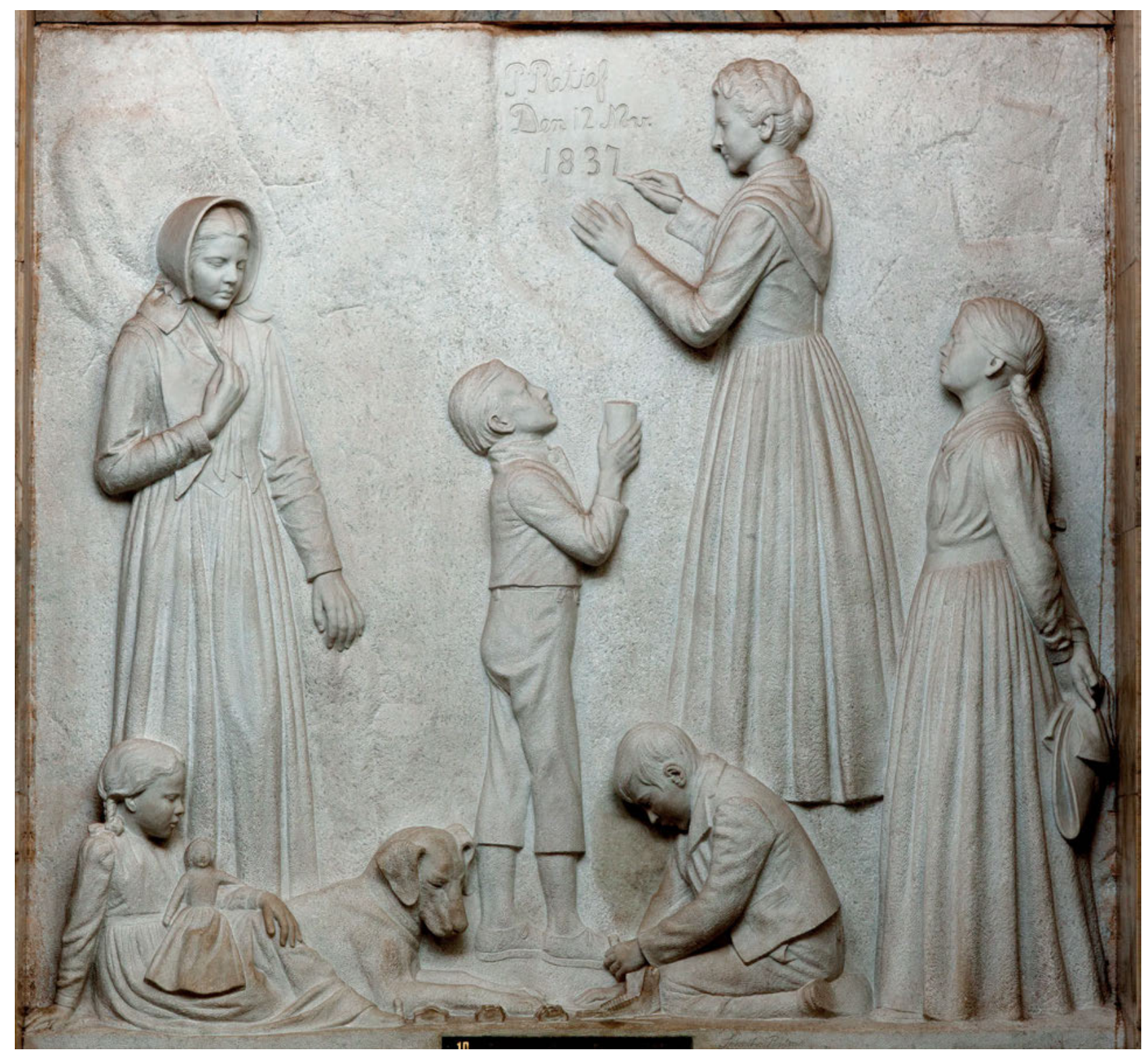

Figure 10.1: D. Debora Retief. 1949. Marble, $2.3 \times 2.39$ m (courtesy of VTM; photo Russell Scott) 


\section{Description}

This is the sole image of the frieze presenting only youthful Boers, chiefly children (fig. 10.1). The main figure is Debora Retief, the eldest daughter of Piet Retief and a young adult of twenty-two, who stands off-centre in profile turned to the left. She is represented as a full-grown woman, her hair in a neat bun and a shawl over her long-sleeved dress with fitted bodice and full-length skirt. The heavy statuesque folds hide her lower body and limbs. She is in an elevated position without visible feet or support, hence hovering strangely on the picture plane. Holding a small brush in her right hand, she has 'just' painted the last stroke of an inscription on a specially smoothed surface of the Retiefklip at top centre, 'P Retief / Den 12 Nov / 1837', the birthday of the governor and commandant-general of the Voortrekkers. In the marble the painted letters of the Dutch words had to be chiselled and they are additionally emphasised by her left hand, which rests immediately below the inscription. Postma must have been shown an image of the actual inscription in the cause of historical accuracy, as she has followed the layout and the form of the letters and numbers that can be seen at Kerkenberg today (fig. 10.8). The uneven face of the rock is also suggested by the roughly worked surface of the upper panel that hints at the height of the overhanging cliff face at Kerkenberg (fig. 10.3).

In front of her, a standing boy assists by holding up a small paint pot. He seems to have outgrown his suit, which mimics adult Voortrekker attire, as the jacket is tight and the trousers too short. The central group, unobscured by overlapping figures, is framed by two impassive girls. The smaller girl in profile on the right looks up to watch Debora's task, holding her kappie with both hands behind her back. The taller one on the left who wears a dress with a fitted bodice and long skirt like Debora, holds the ribbons of her bonnet with her right hand, as she looks down at two children who play on the ground, a boy and a girl with a dog. While all the girls wear long dresses, the bodices of the younger ones are looser, with wide sashes around their waists, and their hair is neatly plaited and tied with ribbons.

In the foreground below on the far left, the small girl is seated on the ground, legs bent and supporting herself on her right arm. With a little doll on her lap she echoes the mother and child group in Inauguration, as though readying herself for an adult role. The boy that she watches is equally engrossed in imitating a grown-up occupation, dressed in a miniature suit. His game mimics a Voortrekker wagon on the move: small 'dolosse' (knucklebones) of sheep or cattle act as imaginary oxen, while a jawbone represents the 'kakebeen' wagon (fig. 10.9), and the boy is in the driver's position. ${ }^{341}$ Half obscured by the girl, a dog intently watches the knucklebones that are carefully laid out along the narrow space in front of its forelegs. 

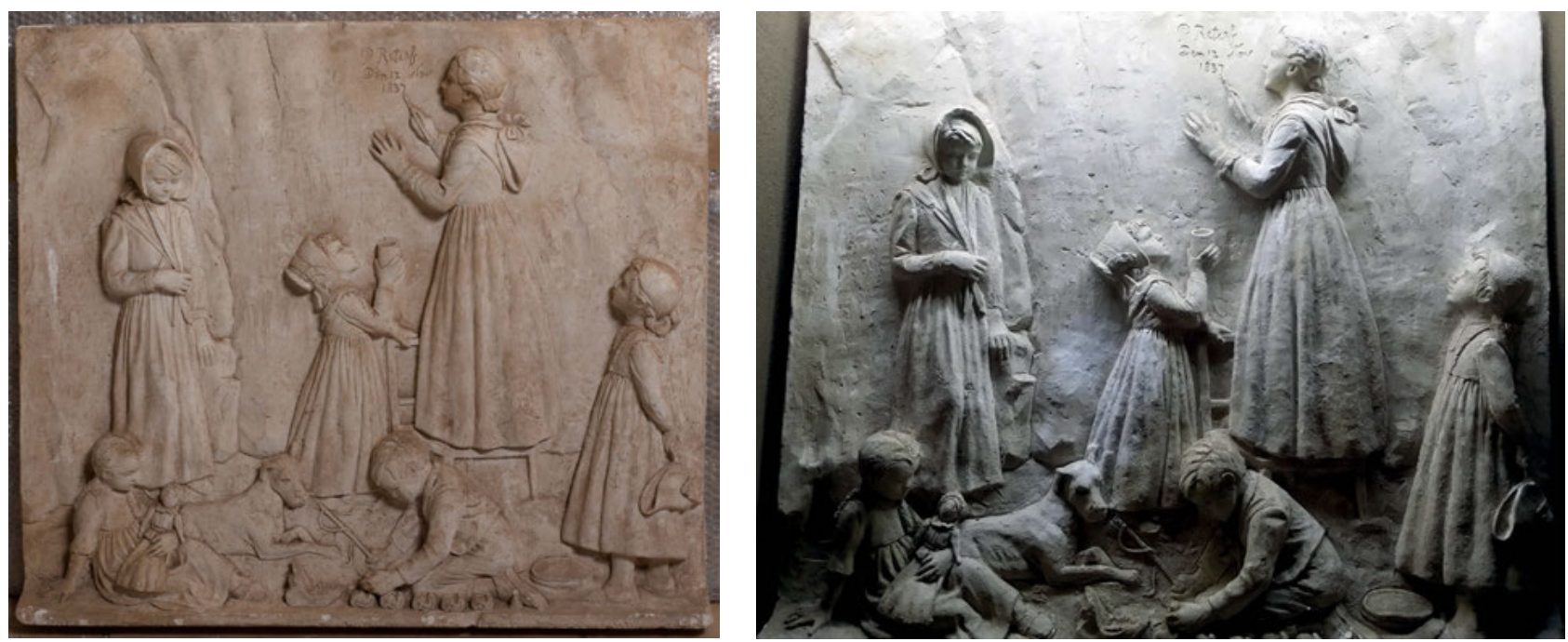

Figure 10.2: B2. Laurika Postma. Debora Retief. 1942-43. Plaster, $77 \times 89 \times 8 \mathrm{~cm}$. Left, maquette photographed in storeroom in 2012; right, in raking light as installed in 2017 exhibition (courtesy of VTM Museum VTM 2184/1-28; photos Russell Scott; the authors)

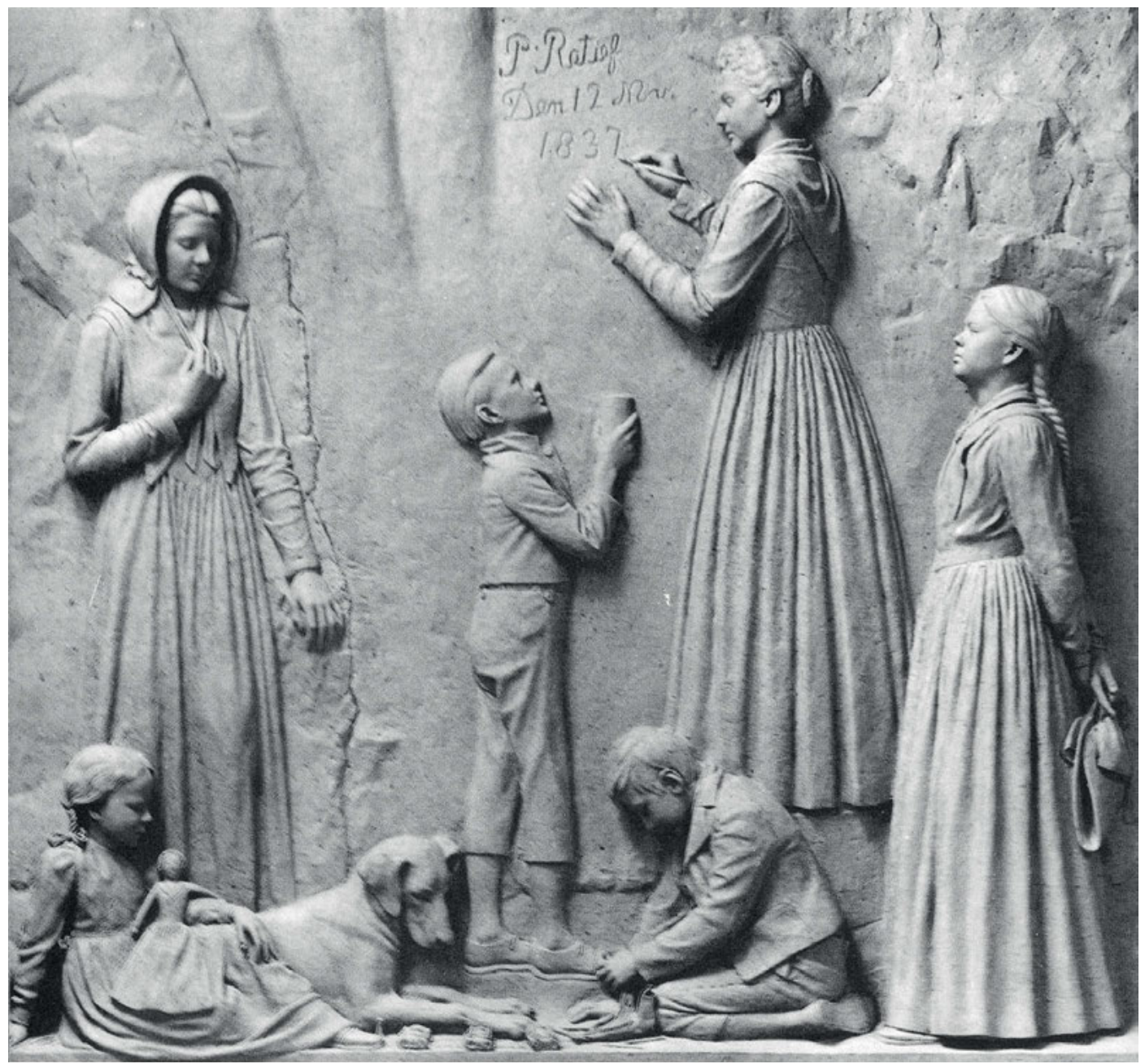

Figure 10.3: C2. Debora Retief. 1943-46. Clay. Full-scale relief (photo Alan Yates; Pillman 1984, 48) 


\section{Developing the design}

As in the case of other panels where there was no Coetzer design, Debora Retief would have started with drawings by the artist, here Laurika Postma, in preparation for modelling the small clay panel (fig. 10.2), but none are known. ${ }^{342}$ While the general composition of the maquette is near to the full-scale clay relief (fig. 10.3), there are substantial differences in detail, style and overall mood. In particular, all the figures are less staged, younger and more childlike, and the texture of a rocky environment is more visible. Debora Retief also seems more spontaneous. Her kappie is pushed back so that it hangs around her neck by its ribbons, and she stands on a chair to reach a high place for her inscription, a believable way to place her in an elevated position. She holds her brush rather awkwardly, and steadies herself with her left hand. A little girl, instead of the boy in the marble relief, holds up the small paint pot with one hand, while the other holds onto the back of the chair, perhaps to steady it. The two framing girls focus attention on Debora Retief. The one on the left is almost the same as in the marble, but younger and less formal. The opposite girl has the chubbiness and shorter dress of a child, and is more directly involved as she watches Debora, her head tilted to suggest her curiosity and concentration. The two children on the ground are also livelier, and we see their dog more fully. The little boy focuses passionately on his game although, despite the little whip in his hand, he is not presented in the driver's position, as the order of the knucklebones and wagon is reversed when compared to the full-scale clay.

This foreground group is reminiscent of the delightful and amusing sketches of children and animals made by a younger Laurika Postma as a very involved older sister in a large and lively family. ${ }^{343}$ The animation of the figures may also reflect the youthful sitters, identified by Hennie Potgieter (fig. 10.4), who gives relatively extensive documentation of them. The architect's daughter Irma Moerdyk modelled Debora Retief (although Martso Strydom was the body model), and her sister Sylva Moerdyk the girl opposite her. Models for the younger children (fig. 10.5) were Lea Botha for the standing girl, ${ }^{344}$ Stephan Joubert for the boy with the paint pot and his sister Stephanie for the girl with the doll who sits next to the family dog, while Billie Kleinhäns was busy with an improvised kakebeenwa.

The narrative in the full-scale clay relief (fig. 10.3) endows Debora Retief with her appropriate years so that she is a young adult, as though the sculptors had been alerted to the fact that she was not a child in 1937, but in fact a young married woman. This change is matched by an upscaling of the ages of all the figures as their poses and attire are formalised, and the bigger participants take up more of the free space around them than is the case in the maquette. In addition, the small girl with the paint pot in the centre is replaced by a taller boy, perhaps to alleviate the predominance of female figures. The scene has lost its spontaneous touch and become more frozen, and in the process of enlarging the figures the chair on which Debora stood disappeared so that she lacks support and appears to levitate. The final marble (fig. 10.1) is a fine copy of the full-scale clay panel

342 At the time the 2017 exhibition was being installed, two plaster maquettes of Debora Retief were to be seen amongst the maquettes waiting to be installed, so close in form that they would have to have been cast from the same mould. But Werner Kirchhoff, who was living with his family at Harmony Hall and was constantly in the studio, is adamant that the one-third-scale maquettes, made on easels set up on the veranda (see fig. 26.5), were cast in the same way as the full-scale clay reliefs, although in a single piece, destroying the clay original and allowing the clay to be reused. Unable to resolve the puzzle, we postulate that the second in fact dated from the conservation of the maquettes from 2014-16 when duplicate copies were made.

343 See, for example, Pillman 1984, 9-11.

344 Van der Walt 1974, who provides photographs of many of the models, names her Leah Botha from Rietfontein. Note that in Part I we confused Gert van der Walt's article, 'Die onbekende voortrekker', with the consecutive one by Chris Barnard ('Die storie van 'n monument ...'), both published in the same 1974 issue of Die Huisgenoot. 


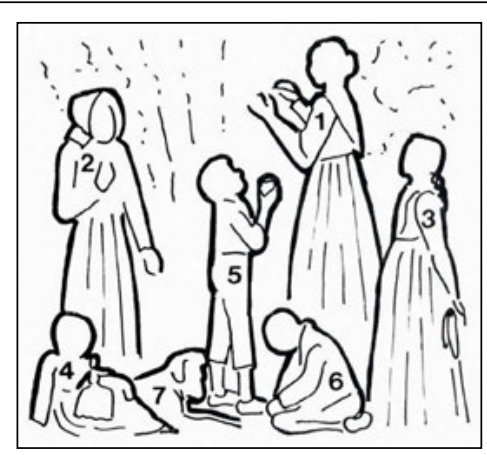

1 Irma Moerdyk, the daughter of the architect of the Voortrekker Monument

2 Sylva Moerdyk, daughter of G. Moerdyk

3 Lea Botha, girl of the neighbourhood

4 Stephanie Joubert

5 Stephan Joubert, brother of Stephanie

6 Billie Kleinhäns

7 Siebie, the Joubert's dog

Figure 10.4: Models for portraits (Potgieter 1987, 21)
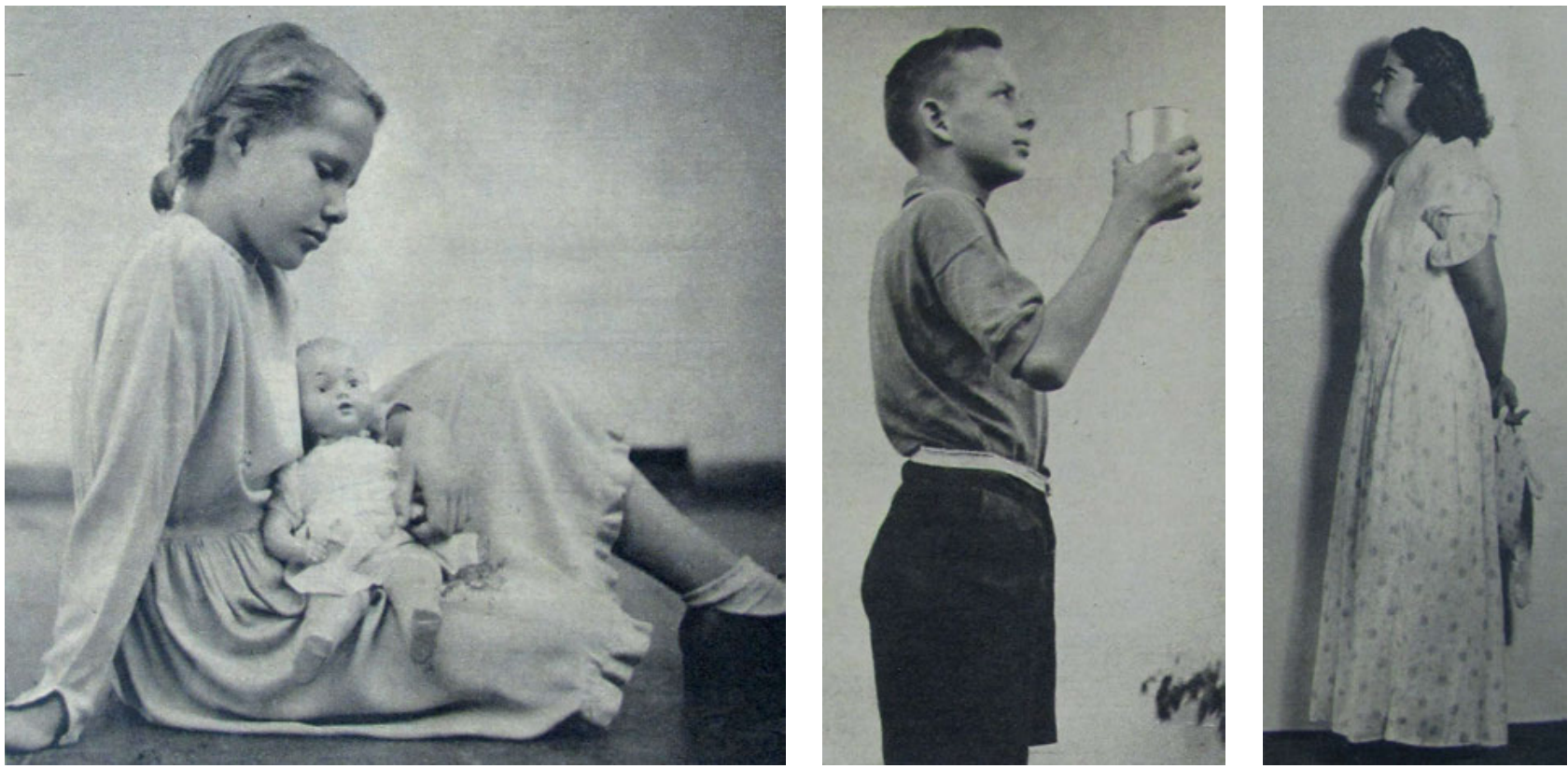

Figure 10.5: Models for younger children in Debora Retief. Stephanie and Stephan Joubert, Leah (Lea) Botha (Van der Walt 1974, 80-82) 
except for one difference which exemplifies the different visual qualities of the two materials. In clay, the vertical rocky structures and general formations of the Retiefklip are crisp and recognisable, while in marble the relief's picture plane appears flattened to an almost uniform mass by the diffused light in the Hall. The reduced visibility of the rock surface means that the lower hand of the girl on the left seems to dangle in its own space, rather than holding onto a protruding piece of stone. 
Figure 10.6:

Topographic Sheets of South Africa (1:50 000).

December 2006. Detail, showing Kerkenberg with Retief Rots, upper right, and trek route over Oliviershoek Pass into Natal (roughly following today's R74 on left of map). 2002 (map 2829CA)
Figure 10.7:

Entrance to rock formation of Retief Rots with

Kerkenberg massif as backdrop (photo courtesy of alamy. com MF8BG7)
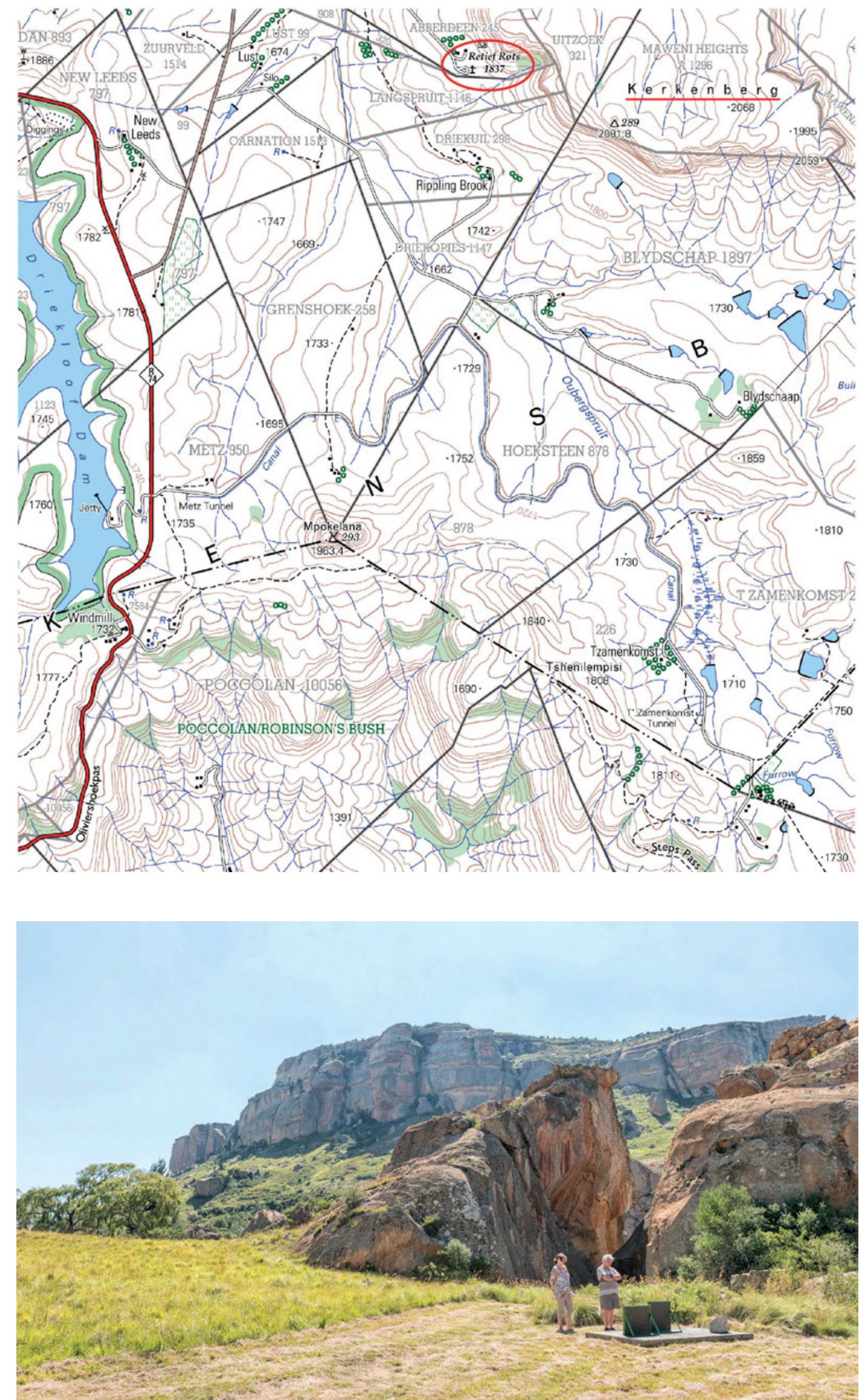


\section{Reading the narrative}

The narrative of this panel refers to a personal event recorded as having taken place one or two days after the arrival of a letter from Retief at his party's camp near Kerkenberg with news from Natal, depicted in Blydevooruitsig (fig. 9.1). The incident was reported by Erasmus Smit, who wrote on 13 November 1837 in his diary:

My wife, C. Liebenberg, and I went up Kerkenberg to view the beautiful formation of the rocks. Three neighbouring spaces which, if we had remained here longer, could have been used as a church or a place of Worship. See now the reasons why we have named this camping site the Kerkenberg. The name of our worthy Governor, on His Excellency's 57th birthday, has been written in green oil paint inside on the rocks by His Excellency's daughter, Debora, and because this rock hangs over to the inside like a vault, it will not easily be washed out by rain or knocked out by hail. ${ }^{345}$

Strictly speaking, Kerkenberg in Smit's account is not the enormous flat-topped mountain (2067 metres high) situated east of the south end of the Sterkfontein dam, beyond the Oliviershoek Pass when travelling from Natal (fig. 10.6), as his naming refers specifically to 'the beautiful formation' of three individual rocks near the mountain's north-western foot (fig. 10.7). ${ }^{346}$ Eventually one of them would be called Retief Rots or Retiefklip, meaning 'Retief rock', after Debora Jacoba Retief $(1815-1900)^{347}$ had painted her father's name and birthdate on it (fig. 10.8). Between the vaulted rock with the inscription and the two adjoining cliffs, as Eily and Jack Gledhill explain, is 'a space large enough to hold 50 to 100 people, and well protected from the elements'. ${ }^{348}$ Smit does not mention Debora Retief's inscription in his diary entry for her father's actual birthday on Sunday, 12 November, but only the next day, as he was preaching at Blydevooruitsig on the Sunday and returned to the Kerkenberg camp only 'after sunset'. ${ }^{349}$ The marking of the birthday was perhaps an intimate situation with only youngsters, possibly family members, participating, which did not necessarily make it into the camp's daily headlines, and may have been discovered only the next day.

More important for the Afrikaner narrative of the Great Trek, however, is how this very personal incident became part of the frieze, and was used to celebrate Retief as governor within the private sphere of Boer family values, here with a particular emphasis on youth. Only relatively late, in 1937, were 'Retiefklip' and 'Kerkeberg' (sic) mentioned as topics for the frieze, but not Debora Retief, although the dedication of a memorial inscription to her in 1937, discussed below, may have prompted the idea. While this scene was undoubtedly an addition to meet the problem of extra panels being required for the corner walls, as discussed in Part I, ${ }^{350}$ the choice was hardly immaterial. The site at Kerkenberg, where the lofty overhanging rock faces reminded the Voortrekkers of a vaulted church, hints at the Christian values so often reiterated in the frieze, and this is supported by the composition. ${ }^{351}$ Whether accidental or not, the way Debora Retief floats in mid-air while

345 Smit trans. Mears 1972, 65 (Dutch text: Smit ed. Scholtz 1988, 96). A restored inscription, protected by a little glazed case, is still to be seen on site (Visagie 2014, 92 fig. 19). Members of the Bethlehem commando that occupied the Oliviershoek Pass on 10 October 1899 (outbreak of the Anglo-Boer War) painted their names next to the Retief inscription.

346 Gledhill and Gledhill $(1980,177)$ provide a helpful description: 'The Kerkenberg is an enormous mass of rock, split by some cataclysm into three pieces.'

347 DSAB 4, 1981, 496-497; Visagie 2011, 415. Although she was since 1832 by marriage Debora Jacoba Meyer (see below), we follow the Official Guide and call her here by her maiden name, Retief, to signal her connection to Piet Retief.

348 Ibid., 177.

349 Smit trans. Mears 1972, 65 (Dutch text: Smit ed. Scholtz 1988, 96).

350 Chapter 3 ('Harmony Hall')

351 For Kerkenberg, see Oberholster 1972, 226-227 no. 25; Raper, Möller and Du Plessis 2014, 231; Visagie 2014, 91-95. A set of detailed photographs is provided at http://www.51countriesandcounting.com/single-post/2017/01/09/Retracing-the-steps-of-the-Voortrekkers---Drakensberg. 


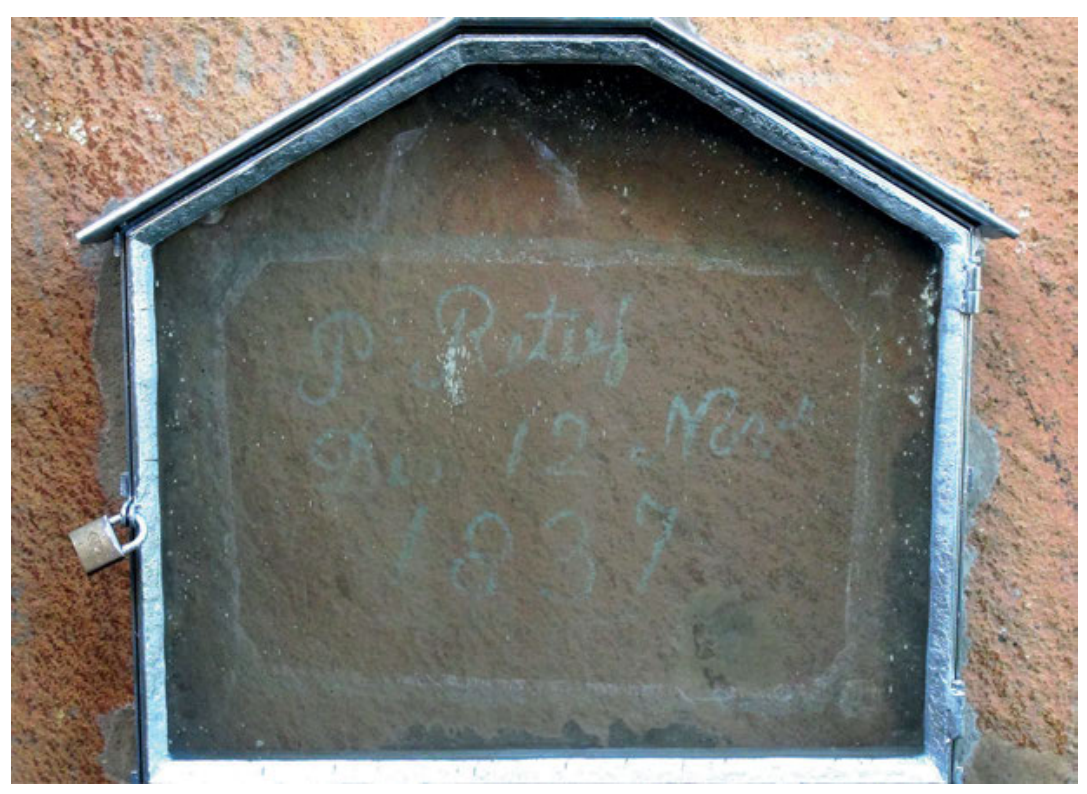

Figure 10.8: 'Retiefklip'. Restored Debora Retief inscription in glazed case (photo courtesy of www.boerenbrit.com/archives/1708/dsc07913\#main)

recording her father's birthday takes away from the personal and anecdotal character of her act. The motif evokes the classical prototype Victory, depicted as either inscribing a virtue or victory on a shield, or crowning a victor to herald in a new era of peace, well known from Roman imperial and early Christian art. ${ }^{352}$ In addition, the mannered stance with which the boy presents the small paint pot, reminiscent of a lay-helper in church, lends a ritualistic flavour. This and the solemn effect of the two framing figures elevate the graffiti-like birthday message into a ceremonial event. With hindsight and the knowledge of Retief's imminent death, the inscription is endowed with the status of a memorial, and the original did indeed become such at its centenary in $1937 .^{353}$

If the panel can be read as a memorial, then one wonders whether Retief's youngest son, Pieter Cornelis (1823-38), ${ }^{354}$ might also be referenced, because of the mode in which the central boy is singled out by his placement and the space around him - although Pieter at fourteen was considerably older than the boy in the relief, and was not present on this occasion since he had already left with his father for the fatal visit to uMgungundlovu. Children who could have been present to witness the event might tentatively be identified as other members of the extended Retief family, offspring of the adopted Greylings, for example, or Debora Retief's own children. Married since 1832 to Lucas Petrus Johannes Meyer (1811-38), ${ }^{355}$ by late 1837 she had already borne three children. Although her two boys, born in 1835 and 1837, died in infancy, her daughter Magdalena, born in 1833, was an appropriate age for the little girl in the foreground of the relief, who with her doll in her lap echoes her mother's constant role of child rearing. Indeed, although it is not represented in the relief, Debora must have been pregnant at the time she celebrated her father's birthday, as

352 Hölscher 1967, 98-131 pls. 11-14 (1st-3rd century AD); Kent, Overbeck and Von Stylow 1973, 169 no. 690 pl. 148 and passim (Late Antiquity); Buranelli, Dietrick, Bussagli, Sica and Bernabei 2007, 52-53 with fig. (Trajan's Column). 353 The site has also been used to memorialise a broader concept of the Trek; for example, commemorative celebrations for the Day of the Vow were arranged there in 2017, as noted in the Voortrekker Monument newsletter for December 2017.

354 Visagie 2011, 415 (Retief, Pieter Cornelis).

355 Ibid., 312. 
another Meyer daughter was born sometime in 1838, probably after the death of the baby's father, who had also accompanied Retief to uMgungundlovu. Since the boys and girls in the panel are never identified in the literature about the frieze, nor the Retief family discussed, any intention to represent specific children seems unlikely. But whether or not such references were intended, the youthfulness of the children has a twofold purpose: it reinforces the generational continuity of Retief's family in particular and the Voortrekkers in general, and also acts as a reminder of the innocence and vulnerability of children. It was they who became victims in brutal confrontations between the Voortrekkers and their foes, such as those depicted later in the narrative of the frieze at Bloukrans, and who also, in less dramatic but equally tragic ways, so often died in infancy on the treks.

In idealising Debora Retief and her act through the formality of the marble relief, the scene was also designed to address Afrikaner virtues of the day woven into the narrative of the Great Trek. As with Debora, the children are endowed with faultless behaviour and immaculate appearance, even in the most inaccessible wilderness. Different sexes and age groups interact with each other in unquestioned harmony and hierarchy, the older children elevated above the younger ones with Debora at the top, all of them in orderly assembly. Remoteness did not even impede their literacy, as the Voortrekkers did not neglect education, already represented in Soutpansberg. That a microcosm of Afrikaner ideals was an intended goal is confirmed in Moerdyk's description:

The happy childhood scene which is also depicted on this panel symbolises the peaceful intentions of the Voortrekkers, a community in search of a new home who laid emphasis upon the family and its ties. ${ }^{356}$

Even as they play on our empathy, Debora Retief and the children are related to gendered role models that embody Afrikaner principles, even the youngest. In the foreground, as we have seen, the children prefigure their forthcoming roles (fig. 10.9), the girl with the doll as a 'volksmoeder', a mother of the Afrikaner nation (see Inauguration), while the boy with his kakebeenwa playfully yet seriously anticipates his future in charge of an ox wagon (fig. 10.10). It is obvious that all the children in this panel play their part as the ideal adults of the future.

More specifically, beginning with Blydevooruitsig, this image and those that follow are arranged to prepare for the drama depicted in the central scene of the Hall's south wall, the murder of Retief and his men. Debora Retief is the most personal scene of the frieze, a kind of ideal family portrait of the upcoming generation, embodied in the Retiefs' lineage. On 4 July 1814, Piet Retief had married Magdalena Johanna de Wet (1782-1855), who was the widow of Field-Cornet Jan Greyling (killed December 1811), and not only adopted their six surviving children into his new family but had four more: Debora Jacoba (1815-1900), Jacobus François (1816, time of death unknown), Magdalena Margaretha (1820, time of death unknown) and Pieter Cornelis, mentioned above, who died with his father in $1838 .^{357}$ Debora Retief followed the example of her parents' large family, and bore twelve children altogether. Because of the untimely death of her first husband, who perished with Retief, she married again in 1839, and after her second husband's death yet again in 1843. It is a reminder of just how often women were widowed on the treks, but frequently remarried to bear yet more children. The Retiefs were a fine example of the extensive families that would ensure the survival of the Voortrekkers and their values, even in the face of the loss of Retief, his eldest stepson Abraham Greyling, his son Pieter and his son-in-law Lucas Meyer at uMgungundlovu on 6 February 1838 (see Murder of Retief).

The Retiefs also exemplify the family networks that shaped the succeeding chapters of Afrikaner history. After her husband's death at uMgungundlovu in February 1838 (see Murder of

356 Official Guide 1970, 46.

357 Gledhill and Gledhill 1980, 50 (marriage with M.J. de Wet), 54 (birth of Debora), 56 (birth of Jacobus), 65 (birth of Magdalena), 86 (birth of Pieter); Visagie 2011, 414-415. 


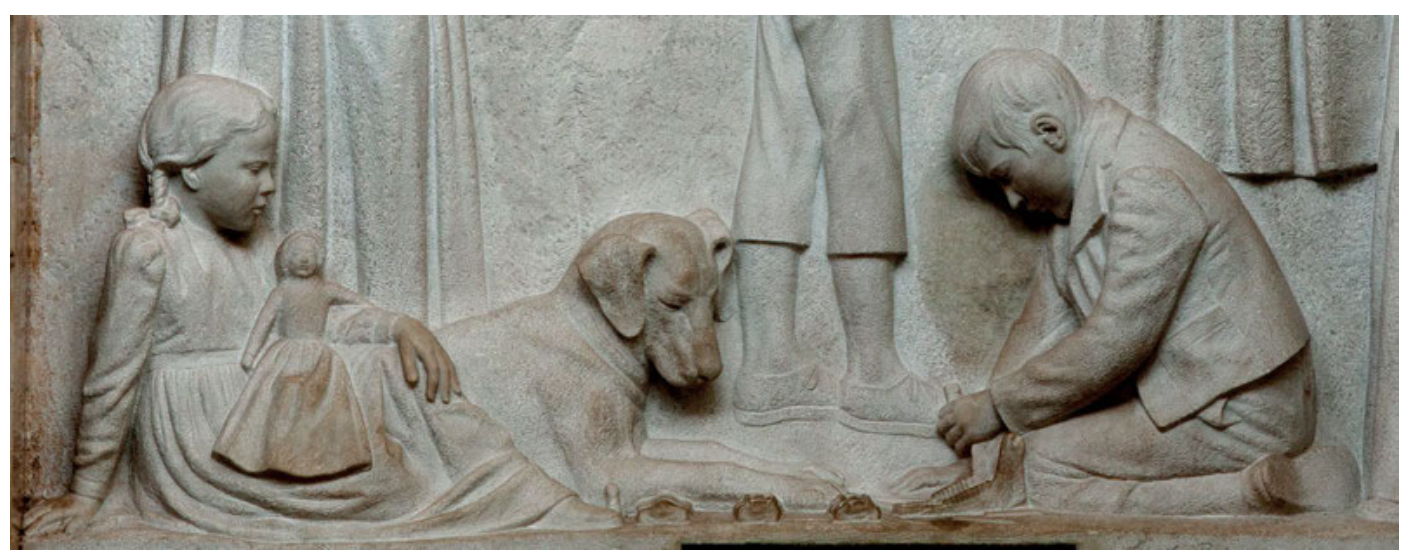

Figure 10.9: Preparing for adult roles in Debora Retief - girl with doll and boy with kakebeenwa. Marble, detail of fig. 10.1 (photo Russell Scott)

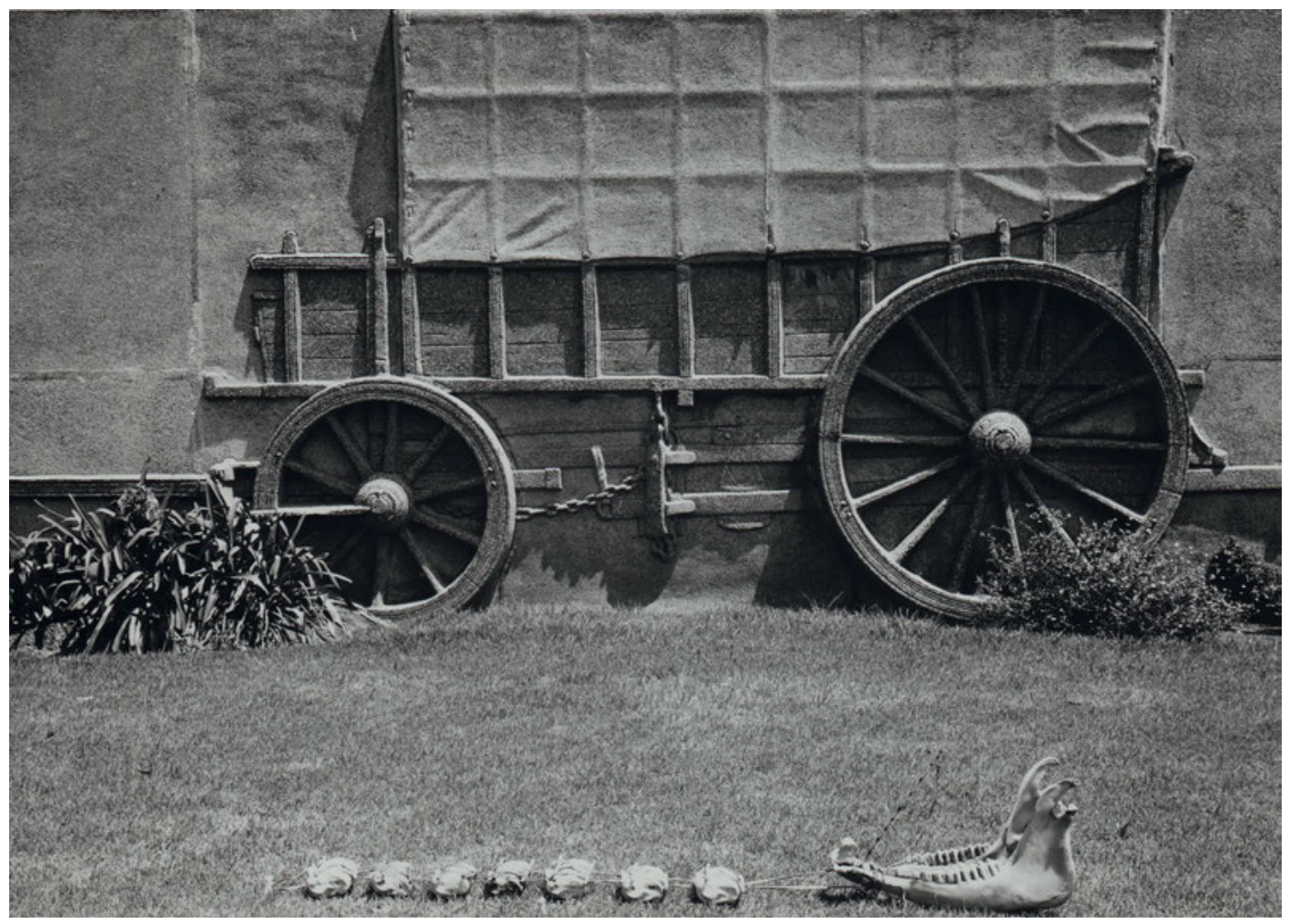

Figure 10.10: Kakebeenwa in front of wagon of the Voortrekker Monument laager (photo courtesy of HF Archives $\mathrm{F}$ 40.1.10 k) 
Retief), Debora Retief remarried with Willem Adolph Landman in 1839 (they had one daughter), ${ }^{358}$ and then in 1843 with Marthinus Wessel (Swart Martiens) Pretorius (1822-64; they had seven children). He was the nephew of another Voortrekker leader, Andries Pretorius (see Pretorius, Blood River, Mpande and Convention), and apparently trekked in 1838 with his famous uncle. ${ }^{359}$ It was appropriately one of their granddaughters, Johanna Christina Pretorius (1878-1975), who unveiled a memorial plaque at Kerkenberg at its 1937 centenary, ${ }^{360}$ which commemorated both her famous great-grandfather Piet and, as scribe, her grandmother Debora. The next year she would lay the Monument's foundation stone with two other women descendants of trekkers. In yet another link to the story of the Monument, Johanna Pretorius was married to Gustav Preller, the admired researcher and recorder of Voortrekker history, ${ }^{361}$ who played an important part in the Historiese Komitee which guided the selection of topics for the frieze.

Fittingly, Retief's centenary inscription acknowledged that it was 'erected by thankful descendants' (opgerig deur 'n dankbare nageslag), who in 1937 attached it to the rock facing the one with the Debora Retief inscription. The central part of the text repeats the incorrect, but by then wellestablished story, that the trekkers heard of Dingane's grant of land in Natal on the day before the actual birthday of Retief (see Blydevooruitsig):

On 11 November Coenraad and Piet Meyer returned with good news that Natal could be occupied and settled in peace. The following day, Retief's 57th birthday, his daughter Deborah wrote her father's name on this rock in commemoration of this achievement. ${ }^{362}$

Debora Retief's inscription, given her strong links with past and present Afrikaner history, reinforced Retief's status as the Great Trek's most celebrated martyr and hero. The very personal yet formal way in which Retief's birthday is celebrated in the frieze transforms his daughter's affectionate private memento of 1837 into a public memorial for the frieze in the Hall of Heroes. Ever since, Debora Retief has underpinned the strong interrelationship between family history and the Afrikaner narrative of the Trek.

358 According to Visagie (2011, 275), he had probably joined the trek in the party of the Voortrekker leader Karel (Carel) Pieter Landman (see ibid., 274). An explanation for why this marriage lasted such a short time is supplied by Debora's mother, when she wrote to her brother-in-law Gideon Retief on 7 July 1840, and mentioned that 'the measles have again robbed me of grandchildren and an upright son in law, my Debora's husband' (Gledhill and Gledhill 1980, 218-219). Schoeman $(1995,140)$ mistakenly assumes that Mrs Retief's letter refers to Debora's first husband, Lucas Meyer, who was in fact not a victim of the measles but of Zulu assault in the murder of Retief's party in 1838.

359 DSAB 4, 1981, 497; Visagie 2011, 389-390. This Pretorius has often been confused with his brother, Marthinus Wessel Pretorius (1819-1901), who was the son of Andries Pretorius, and first president (1857-60) of the ZAR.

$360 \mathrm{https} / /$ www.bloedrivier.org/gelofte/index.php/databasis/ander-monumente/kerkenberg/retiefklip\# agtergrond. A photograph of the inscription is provided at http://www.boerenbrit.com/archives/1708/dsc07918. It is probably not by chance that 'Retiefklip' seemed to have been first mentioned in the Jansen Memorandum (1937) and then 'Kerkeberg' in Moerdyk's Voortrekker Monument in the centenary year in 1938.

361 See Part I, Chapter 1 ('The Monument Committee').

362 'Op 11 November het Coenraad en Piet Meyer teruggekeer met die blyde tyding, dat Natal in vrede besit en bewoon mag word. Die volgende dag - Retief se 57se verjaardag - het sy dogter, Deborah uit dankbaarheid vir wat haar vader verkry het, sy naam op hierdie rots geskryf.' Our English quotation follows the English inscription, donated by students of the Technicon Pretoria and Terraz, and set up in 1986 next to its Afrikaans forerunner. A photograph of the inscription is provided at http://www.boerenbrit.com/archives/1708/dsc07919. 
